\title{
ZONASI MINI MARKET DI KOTA PALOPO SUATU UPAYA PERLINDUNGAN PASAR TRADISIONAL DAN WARUNG KECIL
}

\author{
Abd. Kadir Arno \\ Fakultas Ekonomi dan Bisnis Islam Institut Agama Islam Negeri (IAIN) Palopo \\ abdulkadir.arno@iainpalopo.ac.id
}

Nur Ariani Aqidah

Fakultas Ekonomi dan Bisnis Islam Institut Agama Islam Negeri (IAIN) Palopo nurariani_aqidah@iainpalopo.ac.id

\begin{abstract}
Regional Regulation Number 9 of 2012 on the Spatial Planning of the City of Palopo became a reference in the zoning of minimarkets in Palopo City as a form of implementation and implementation of Presidential Regulation Number 112 of 2007 about Arrangement and Development of Traditional Markets, Shopping Centers and Modern Shops, in regulating permits from the establishment of Minimarkets in Palopo City. At present the Palopo City Government only gives establishment permits based on regional zoning in 5 sub-districts from 9 sub-districts in Palopo City
\end{abstract}

Keywords: Zoning Mini Market

\begin{abstract}
Abstrak
Peraturan Daerah Nomor 9 Tahun 2012 Tentang Rancangan Tata Ruang Wilayah Kota Palopo menjadi rujukan dalam zonasi minimarket di Kota Palopo sebagai bentuk pelaksanaan dan implementasi dari Peraturan Presiden Nomor 112 Tahun 2007 Tentang Penataan dan Pembinaan Pasar Tradisional Pusat Perbelanjaan dan Toko Modern, dalam mengatur izin dari pendirian Minimarket di Kota Palopo. Saat ini Pemerintah Kota Palopo hanya memberikan izin pendirian berdasarkan zonasi daerah di 5 kecamatan dari 9 kecamatan di Kota Palopo
\end{abstract}

Kata Kunci : Zonasi Mini Market 


\section{PENDAHULUAN}

Keberadaan pasar tradisional dan kios kecil masyarakat kini terancam dengan meningkatnya kehadiran pasar modern, khususnya supermarket, hypermarket dan mini market. Nielsen Retail (2017) merilis data jumlah pemain minimarket tingkat nasional sampai Maret 2017 mencapai 28.610 toko, terdiri dari Indomaret 14.200 toko, Alfamart 12.700 toko, Alfa Midi 1.300 toko Circle K 410 toko. Dari sisi persentase pertumbuhan pasar modern di Indonesia adalah 31,4\% per tahun, sedangkan pasar tradisional telah mengalami kontraksi $8 \%$ per tahun

Melihat hal ini Peraturan Presiden Nomor 112 Tahun 2007 tentang penataan dan pembinaan pasar Tradisional, pusat perbelanjaan, serta toko modern dikeluarkan untuk menyusun dan mengembangkan pasar tradisional, pusat perbelanjaan, dan toko modern (Restu, 2010) diikuti oleh peraturan pendukung lainnya, yaitu Peraturan Menteri Perdagangan Nomor 53 Tahun 2008 yang memuat pengaturan tentang pendirian pasar tradisional, pusat perbelanjaan, dan toko modern termasuk zonasi, dan perizinan.

Sebagaimana telah dijelaskan sebelumnya bahwa pasar tradisional mempunyai fungsi dan peranan yang tidak hanya sebagai tempat perdagangan tetapi juga sebagai peninggalan kebudayaan yang telah ada sejak zaman dahulu. Perkembangan pasar modern dalam suatu daerah tidak dapat dihindari karena disisi lain pemerintah daerah di tuntut untuk meningkatkan pertumbuhan ekonomi daerahnya, salah satu indikator untuk meningkatkan pertumbuhan ekonomi yaitu menumbuhkan iklim investasi di daerah yang dapat di peroleh dari industri ritel salah satunya dari industri pasar modern.

Menurut Edwin Lioe, Research analyst DBS Vickers Securities mengemukakan bahwa pertumbuhan yang lebih cepat adalah mini market yang diprediksi tumbuh $15.5 \%$ di tahun 2018, faktor yang mempengaruhi pertumbuhan cepat tersebut yaitu kemudahan untuk membangun mini market dibanding jenis gerai lainnya (Septarini, 2016). Salah satu daerah yang menjadi sasaran berkembanganya pasar modern (minimarket seperti Alfamidi, Alfamart dan Indomaret) yaitu Kota Palopo yang di tahun 2018 sudah berdiri 27 minimarket yang tersebar diseluruh Kota Palopo. 
Perkembangan pasar modern yang ada di Kota Palopo tidak luput dari peran pemerintah dalam hal memberikan perizinan pendirian, karena pemerintah memiliki hak untuk mengatur keberadaan pasar tradisional dan pasar modern dalam bentuk peraturan. Namun, aturan yang dibuat oleh pemerintah tidak boleh diskriminatif dan tidak membuat dunia bisnis stagnan. Para pedagang baik pedagang kecil, menengah dan besar, harus memiliki kesempatan yang sama dalam berusaha.

Di satu sisi, keberadaan pasar modern memiliki nilai positif bagi konsumen, tetapi di sisi lain, keberadaan pasar modern juga menjadi ancaman bagi keberadaan pasar tradisional. Dampak yang dirasakan jika situasi ini dibiarkan, maka terdapat ribuan bahkan jutaan pedagang kecil akan kehilangan mata pencaharian mereka. Pasar tradisional dan toko-toko kecil mungkin tenggelam seiring dengan tren perkembangan ritel dunia yang didominasi oleh pasar modern saat ini yang sedang menanjak di tengah masyarakat, mulai dari berdiri di pinggir jalan besar hingga memasuki area pemukiman di mana jarak antara satu sama lain berdekatan satu sama lain meskipun berdekatan.

Senada dengan hal tersebut hasil kajian Mujahid dkk (2018) menunjukkan bahwa kehadiran pasar modern telah mengancam eksistensi pasar tradisional dalam hal penurunan omzet penjualan hal tersebut disebabkan oleh meningkatnya jumlah minimarket setiap tahun dan jarak antara minimarket dengan warung kecil yang saling berdekatan, berhadapan dan bahkan saling berdampingan.

Penurunan omzet penjualan pasar tradisional sebenarnya bukan saja karena hadirnya pasar modern saja akan tetapi hampir semua pasar tradisional di Indonesia masih berjuang dengan masalah internal yang ada seperti manajemen pasar yang buruk, minimnya fasilitas infrastruktur dari pasar tradisional, banyaknya pungutan retribusi dan kurangnya bantuan permodalan yang tersedia untuk pedagang. Masalah tersebut yang dihadapi oleh pasar tradisional secara tidak langsung dapat menguntungkan pasar modern (Suryadarma et al, 2007). Selain itu, penelitian Suryadarma et al (2007) menyimpulkan bahwa keberadaan pasar modern dapat mempengaruhi penurunan kinerja pasar tradisional, meskipun secara kuantitatif tidak memiliki pengaruh signifikan. Salah satu penyebab yang 
dapat menurunkan kinerja pasar tradisional yaitu faktor internal yang dapat mengakibatkan pasar tradisional tidak dapat bersaing dengan pasar modern.

Demikian pula Aryani (2011) menyimpulkan bahwa ada perbedaan pendapatan pedagang sejak adanya pasar modern. Argumen-argumen lain sebagian besar terkandung dalam tulisan di jurnal ilmiah termasuk (Oemar, 2010), (Sugiono, 2012), (Sarwoko, 2008), (Tri, 2011), (Rushan, 2016) (Sihotang, 2014) yang mengangkat tema tentang dampak pasar modern terhadap pasar tradisional dan usaha masyarakat di berbagai kota di Indonesia.. Beberapa permasalahan yang terkait dengan pengembangan pasar tradisional adalah :

\section{Revitalisasi Pasar Tradisional}

Eksistensi pasar tradisional di perkotaan dewasa ini semakin terancam oleh maraknya pembangunan pasar modern. Kesan yang ada di benak masyarakat tentang pasar tradisional identik dengan tempat berbelanja yang hanya dikunjungi oleh kelompok masyarakat kelas bawah, tempat berbelanja kotor dam becek dan semrawut, tidak aman karena banyak pencopet membuat sebagian masyarakat enggan berbelanja di pasar tradisional.

Hal ini dapat menjadi ancaman yang serius bagi keberlangsungan usaha para pedagang di pasar tradisional, yang pada umumnya merupakan pedagang kecil dan menengah, oleh karena itu pemerintah harus menyadari bahwa keberadaan pasar tradisional sebagai pusat kegiatan ekonomi sangat penting bagi seluruh masyarakat sehingga pemerintah harus ikut andil dalam hal pengaturan dan pengelolaan pasar tradisional.

Pemerintah harus serius dalam mengelola dan mempertahankan keberadaan pasar tradisional perhatian tersebut dibuktikan dengan merevitalisasi pasar tradisional yang ada. Salah satu tujuan dari revitalisasi pasar tradisional adalah agar dapat merubah kesan negatif yang ada pada pasar tradisional menjadi tempat yang nyaman dan aman bagi konsumen sehingga tertarik untuk datang berbelanja di pasar tradisional.

2. Regulasi

Pemerintah mempunyai kewajiban untuk memperhatikan apa yang masyarakat dan dunia bisnis butuhkan dalam sektor-sektor usaha datau kegiatan 
ekonomi lainnya, sehingga pelaku usaha dalam melakukan interaksi kegiatan perekonomian dapat dilakukan bersama-sama secara kompetitif. Selain itu pemerintah juga dapat menjamin pengaturan kegiatan ekonomi yang berdasarkan prinsip anti monopoli yang menghormati prinsip persaingan usaha yang sehat.

Selain kewajiban pemerintah untuk mengatur praktik bisnis yang dapat merugikan warga dalam suatuan ketentuan hukum atau peraturan perundangundangan. Jika intervensi pemerintah dapat dilaksanakan secara sistematis dan benar, maka terjadi persaingan usaha yang sehat (adil). Di sisi lain, persaingan yang adil menghasilkan alokasi sumber daya yang rasional. Karena itu, pemerintah harus dilibatkan dalam menciptakan aturan-aturan yang adil bagi pelaku bisnis, untuk melindungi pihak-pihak yang lemah dari eksploitasi ekonomi dari pihak-pihak yang kuat.

Pemerintah sebagai pihak yang berhak menerbitkan peraturan perundangan (legislator) harus mengatur secara jelas dan transparan; terkait sanksi pidana dan sanksi administratif terhadap pelaku bisnis yang melanggar; dan bertindak sebagai wasit yang adil, jujur, dan bertanggung jawab dalam dunia usaha. Apabila dikaitkan dengan maraknya pertumbuhan pasar modern dewasa ini, maka tampak bahwa pemerintah bertekad untuk mempertahankan pasar tradisional

Melihat hal ini maka tulisan ini bertujuan untuk memberikan gambaran kebijakan pemerintah dalam Zonasi Minimarket di Kota Palopo sebagai upaya untuk melindungi warung-warung kecil sebagai bentuk pengimplementasian Peraturan Presiden (Perpres) Nomor 112 Tahun 2007 sebab selain peraturan yang di keluarkan oleh pemerintah pusat dan kementerian yang terkait tersebut di atas pemerintah daerah juga merupakan pihak yang berkompeten dalam mengimplementasikan peraturan tersebut (Wasi, 2010). Metode analisis data dalam artikel ini menggunakan analisis deskriptif kualitatif, yaitu dengan menguraikan dan menjelaskan kajian tertulis berkaitan dengan kondisi perkembangan pasar modern yang ada di Kota Palopo. 


\section{DINAMIKA PERKEMBANGAN MINI MARKET}

Peraturan Presiden Nomor 112/2007 tentang Pengaturan dan Pengembangan Pasar Tradisional, Pusat Perbelanjaan dan Toko Modem, para pengelola jaringan pasar mini adalah pelaku bisnis yang menjalankan kegiatan bisnis pasar modern melalui sistem manajemen dan distribusi terpadu ke jaringan outlet. Minimarket menerapkan sistem layanan mandiri (swalayan), di mana pembeli mengambil item yang diperlukan dan membayarnya ke kasir. Dengan sistem ini kebutuhan untuk berbelanja di tempat yang nyaman sedikit terisi. Perilaku konsumen yang menyukai belanja di tempata yang bersih, keren, dan rapi membuat minimarket lebih baik daripada pasar tradisional dan warung-warung kecil (Ma'ruf, 2005: 84).

Bisnis ritel di Indonesia dapat dibagi menjadi 2 kelompok utama, yaitu Ritel Tradisional Ritel dan Ritel Modern (www.aprindo.org). Retail modern sebenarnya adalah pengembangan dari ritel tradisional yang dapat diklasifikasikan menurut bentuk, ukuran, tingkat modernitas, dll., Sehingga berbagai jenis bisnis ritel dapat ditemukan. Peritel modern ini muncul dan berkembang seiring dengan perkembangan perekonomian, teknologi dan gaya hidup masyarakat, di mana orang-orang sekarang ini membutuhkan lebih banyak kenyamanan dalam berbelanja. Mobilitas dan aktifitas dari kehidupan yang sibuk membuat kebutuhan akan peningkatan layanan belanja oleh karena itu kesempatan ini yang ditangkap oleh peritel modern.

Peraturan pemerintah tentang bisnis ritel memberikan pembatasan pada ritel tradisional dan ritel modern. Peraturan Presiden No. 112/2007 tentang Peraturan dan Pengembangan Pasar Tradisional, Pusat Perbelanjaan dan Toko Modem, memberikan batasan-batasan berikut dalam pasal 1 sebagai berikut:

\section{Pasar Tradisional}

Pasar tradisional adalah pasar yang dibangun dan dikelola oleh, Pemerintah Daerah, Sektor Swasta, BUMN/BUMD, termasuk kerjasama sektor swasta dengan tempat usaha yang dimiliki/dikelola oleh pedagang kecil dan menengah dengan proses pembelian dan penjualan barang dagangan melalui tawar-menawar. 
Pasar tradisional yang memiliki nilai-nilai historis, tidak dapat diubah atau dijadikan pasar modern kecuali upaya revitalisasi agar menjadi pasar tradisional yang bersih, teratur, nyaman, aman, memiliki keunikan, menjadi ikon kota, memiliki nilai sebagai bagian dari industri pariwisata

\section{Toko Modern}

Toko modern merupakan toko yang menjual berbagai jenis barang eceran dalam bentuk Hipermart, Supermarket Dept. Store maupun Minimarket, yang menggunakan sistem pelayanan mandiri. Pembatasan Toko Modern ini ditekankan dalam Pasal 3, dalam hal luas lantai penjualan sebagai berikut: a) Hypermarket dan Perkulakan > $5.000 \mathrm{~m}^{2}$ (lima ribu meter persegi); b) Supermarket, $400 \mathrm{~m}^{2}-$ $500 \mathrm{M}^{2}$ (empat ratus meter persegi-hingga lima ribu meter persegi); c) Departmen Store $>400 \mathrm{~m}^{2}$ (empat ratus meter persegi) d) Minimarket, $<400 \mathrm{~m}^{2}$ (empat ratus meter persegi);

Dari ketiga jenis ritel modern di atas yaitu hypermarket, supermarket, minimarket ketiganya memiliki fitur yang sama dalam model penjualannya, yang dilakukan langsung pada pengguna akhir dengan pelayanan mandiri, dalam arti kata pembeli mengambil barang dari rak yang disediakan dan membayar ke kasir. Persamaan lainnya, yaitu dari jenis barang yang diperdagangkan adalah berbagai jenis kebutuhan rumah tangga termasuk kebutuhan sehari-hari. Adapun perbedaan diantara ketiganya, terletak pada jenis produk dan jumlah item yang diperjualbelikan, area dan luas lantai usaha, lahan parkir, serta permodalan yang dibutuhkan. Untuk lebih jelasnya deskripsi dari ketiga jenis ritel modern tersebut sebagai berikut:

\section{a.Minimarket}

Minimarket merupakan pengembangan dari model Mom \& Pop Store menjadi sebuah toko yang ukurannya relatif kecil, di mana manajemen pengelolaannya lebih modern, dengan jenis barang yang diperjual belikan lebih banyak. Sedangkan Mom \& Pop Shop yang dikenal sebagai toko kelontong adalah toko yang dikelola secara tradisional yang ukurannya juga relatif kecil, umumnya terletak di pemukiman/ perumahan penduduk yang hanya menjual barang kebutuhan pokok/harian untuk masyarakat. 


\section{b. Supermarket}

Supermarket adalah bentuk outlet ritel yang operasinya relatif besar, berbiaya rendah, dengan volume penjualan yang cukup tinggi, dengan sistem pelayanan yang dirancang untuk memenuhi kebutuhan konsumen yang disebut sebagai self service dan dapat dikelompokkan berdasarkan jenis produk, seperti daging, produk olahan, makanan kering, dan barang produk non-makanan seperti mainan, majalah, peralatan rumah tangga lainnya, (Sopiah, 2008: 50-51).

\section{c. Hipermart}

Hipermarket adalah bentuk dari salah satu pasar modern yang mempunyai bangunan gedung sangat besar dan luas yang digunakan untuk tempat dari barangbarang yang diperdagangkan. Selain bangunan dan tempat yang luas, hipermarket juga menyediakan lahan parkir yang luas.

Dalam perkembangannya saat ini, Supermarket tidak terlalu favourable lagi di tengah masyarakat yang disebabkan oleh kedekatan lokasi usaha dengan konsumen, Supermarket tidak dapat bersaing dengan Minimarket dalam hal lokasi usaha sebab biasanya minimarket banyak berlokasi di perumahan penduduk), sedangkan untuk berbagai macam barang, Supermarket disaingi oleh Hypermarket yang menawarkan lebih banyak pilihan barang yang disediakan.

\section{KEBIJAKAN PEMERINTAH KOTA PALOPO DALAM ZONASI MINIMARKET}

Salah satu bentuk kebijakan yang telah diputuskan oleh Pemerintah Kota Palopo yaitu memberikan izin pendirian mini market. Pemberian izin pendirian mini market tersebut di berikan kepada sektor swasta dengan berbagai pertimbangan sebab perkembangan minimarket merupakan suatu keniscayaan yang tidak dapat dihindari, oleh sebab itu hal yang paling urgent yang harus ditangani membuat regulasi dan aturan-aturan terkait mini market. Regulasi yang sangat penting dibuat oleh Pemerintah Kota Palopo adalah menyangkut zonasi minimarket, karena tidak sering masalah zonasi Minimarket menjadi 
permasalahan dengan keberadaan pasar tradisional yang sudah lebih dulu ada dan merasa dirugikan dengan keberadaan Minimarket.

Sebenarnya pemerintah Kota Palopo telah menerapkan konsep zonasi mini market tersebut sebagaimana yang tertuang dalam Peraturan Presiden No. 112/2007 yang di dalam peraturan tersebut menyatakan bahwa Lokasi pendirian Pusat Perbelanjaan dan Toko Modern wajib mengacu pada Rencana Tata Ruang Wilayah Kabupaten/Kota, dan Rencana Detail Tata Ruang Kabupaten/Kota, termasuk Peraturan Zonasinya, oleh karena itu sudah menjadi keharusan Pemerintah Kota Palopo di tuntut untuk membuat kebijakan mengenai pengelolaan Mini market dalam bentuk peraturan pendukung yang tetap mengacu pada peraturan presiden tersebut.

Di Kota Palopo sendiri, masalah zonasi minimarket belum mempunyai aturan yang jelas dan mengikat serta berdiri sendiri. Sehingga yang menjadi acuan dalam zonasi minimarket yaitu Peraturan Daerah No. 9 Tahun 2012 tentang Rancangan Tata ruang Wilayah dan Rancangan Detail Tata Ruang Kota Palopo. Dalam penataan Minimarket Pemerintah Kota Palopo memutuskan untuk memberikan izin pendirian mini market hanya pada 5 kecamatan dari 9 kecamatan yang ada di Kota Palopo. 5 kecamatan tersebut adalah: a) Kecamatan Wara b) Kecamatan Wara Selatan c) Kecamatan Wara Timur d) Kecamatan Wara Utara dn e) Kecamatan Bara.

Pemerintah Kota Palopo memberikan kewenangan kepada beberapa instansi untuk pengaturan serta perizinan pendirian kepada bisnis minimarket di Kota Palopo. Adapun pihak-pihak yang diberikan kewenangan dalam penataan dan perizinan Minimarket di Kota Palopo adalah sebagai berikut: a) Badan Penanaman Modal dan Pelayan Perizinan Terpadu Kota Palopo; b) Dinas Tata Ruang Kota Palopo; c) Dinas Koperasi Usaha Mikro Kecil dan Menengah Perindustrian dan Perdagangan Kota Palopo; d) Badan Lingkungan Hidup; e) Dinas Perhubungan; f) Satpol PP; dan g) Pemadam Kebakaran. Masing-masing instansi atau badan tersebut memiliki kewenangannya sendiri, yang antara satu dengan lainnya memiliki koordinasi untuk menentukan penerbitan izin-izin pendirian mini market yang diajukan oleh pihak swasta. 
Pengaturan mengenai zonasi antara minimarket dan pasar tradisional telah diatur secara terperinci dalam Peraturan Presiden No.112/2017 yang mengatur masalah zonasi, bagaimana perlindungan pasar tradisional serta ekspansinya, dan juga mengatur bagaimana supaya pengaturan lokasi pasar tradisional dan ritel modern bisa menjadi lebih baik.

Arah kebijakan dari Peraturan Presiden tersebut adalah untuk memberdayakan pasar tradisional agar dapat tumbuh dan berkembang bersama secara harmonis, saling membutuhkan dan saling menguntungkan serta dpat memperkuat satu sama lain dalam bidang perekonomian. Selain itu, juga memberikan pedoman serta panduan dalam hal managemen pengelolaan pasar tradisional, dan toko modern, memberikan aturan-aturan yang berasaskan keadilan dan saling menguntungkan antara satu dengan yang lainnya.

Pemerintah Daerah berkewajiban memberikan perlindungan kepada pasar tradisional dan pelaku-pelaku usaha yang ada di dalamnya termasuk kejelasan dan kepastian hukum tentang status hak pakai lahan pasar. Dalam melakukan perlindungan kepada Pasar Tradisional serta pelaku-pelaku usaha yang ada didalamnya, Pemerintah Daerah berkewajiban memberikan perlindungan dalam aspek:

1.Alokasi usaha yang strategis dan menguntungkan pasar tradisional;

2.Kepastian hukum dan jaminan usaha di pasar modern baik dalam aspek lokasi maupun aspek lainnya;

3.Kepastian hukum dalam status hak sewa, untuk menjamin keberlangsungan usaha, jika terjadi musibah yang menghancurkan harta benda yang diperdagangkan

Dalam upaya pemberdayaan pasar tradisional Pemerintah Daerah berkewajiban melakukan :

1.Pembinaan terhadap pasar tradisional, serta pelaku-pelaku usaha yang ada didalamnya;

2.Pemberian subsidi kepada pasar tradisional, serta pelaku-pelaku usaha yang ada didalamnya; 
3.Peningkatan kualitas dan sarana pasar tradisional serta pelaku-pelaku usaha yang ada didalamnya;

4.Pengembangan pasar tradisional, serta pelaku-pelaku usaha yang ada didalamnya;

5.Memfasilitasi pembentukan wadah atau asosiasi pedagang sebagai sarana memperjuangkan hak dan kepentingan para pedagang;

6.Mengarahkan dana sharing yang berasal dari Pemerintah kepada

Pemerintah Daerah dalam rangka membangun pasar.

Aspek-aspek yang harus diperhatikan oleh pemerintah, sehingga keberadaan pasar modern dapat diterima oleh semua lapisan masyarakat, khususnya pedagang tradisional, adalah:

Pertama, pemerintah menetapkan rencana tata ruang wilayah, agar pasar modern tidak didirikan di sembarang tempat. Lokasi pembangunan pasar modern harus berjauhan dari lokasi pasar tradisional, sehingga konsumen cenderung memilih pasar tradisional dengan mempertimbangkan jarak ke pasar modern.

Kedua, pemerintah harus membatasi jam operasi pasar modern. Hal ini dilakukan sebagai perlindungan bagi pasar tradisional dan warung-warung kecil sehingga pasar tradisional dapat terus dapat tumbuh dan berjalan sebagaimana mestinya.

Ketiga, pemerintah harus mampu membuat kebijakan mengenai kerjasama antara pelaku bisnis pasar modern dan pemerintah mengenai tenaga kerja yang akan digunakan di pasar modern, karena salah satu efek positif dari pasar modern adalah ketenagakerjaan. Pemilik pasar modern harus memberikan peluang yang lebih besar bagi orang-orang di sekitar pasar modern untuk menjadi pekerja dalam rangka untuk meningkatkan perekonomian masyarakat sekitar.

Keempat, penentuan pajak operasional dan perizinan pasar modern yang lebih besar, sehingga dengan pajak yang lebih besar di pasar modern, harga barang di pasar modern otomatis menjadi lebih tinggi dan mahal disbanding dengan harga di pasar tradisional. Ini akan membuat orang-orang dari kelas bawah berpikir jika ingin berbelanja di pasar modern, sehingga akan cenderung berbelanja di pasar tradisional. 
Kelima, karena pasar tradisional yang identik dengan kata-kata kotor, dan bau, menjadi kurang menarik bagi orang-orang sibuk, terutama bagi orang-orang kelas menengah atas maka pemerintah harus menjadi dapat membangun pasar tradisional yang lebih baik. Selain itu, pemerintah harus dapat membuat kebijakan yang memihak pedagang pasar tradisional dengan mengedepankan pembangunan dan pengembangan pasar tradisional yang lebih baik, sehingga dapat menarik kembali minat masyarakat untuk berbelanja di pasar tradisional.

\section{PENUTUP}

Acuan dalam zonasi minimarket di Kota Palopo berdasarkan Peraturan Daerah No. 9 Tahun 2012 tentang Rancangan Tata ruang Wilayah Kota Palopo dan Rancangan Detail Tata Ruang Kota Palopo sebagai bentuk dari pengimplemtasian Perpres No 11 tahun 2007. Sebagai bentuk perlindungan bagi bagi warung-warung kecil Pemerintah Kota Palopo dalam menata Minimarket memberikan izin pendirian mini market hanya pada 5 kecamatan dari 9 kecamatan yang ada di Kota Palopo. 5 kecamatan tersebut adalah: a) Kecamatan Wara b) Kecamatan Wara Selatan c) Kecamatan Wara Timur d) Kecamatan Wara Utara dn e) Kecamatan Bara. Adapun pihak-pihak yang diberikan kewenangan dalam penataan dan perizinan Minimarket di Kota Palopo adalah sebagai berikut: 1) Badan Penanaman Modal dan Pelayan Perizinan Terpadu Kota Palopo ; 2) Dinas Tata Ruang Kota Palopo ; 3) Dinas Koperasi Usaha Mikro Kecil dan Menengah Perindustrian dan Perdagangan Kota Palopo ; 4) Badan Lingkungan Hidup ; 5) Dinas Perhubungan ; 6) Satpol PP ; dan 7) Pemadam Kebakaran

\section{DAFTAR PUSTAKA}

Aryani, D. (2011). Efek Pendapatan Tradisional dari Ramainya Kemunculan Minimarket di Kota Malang. Jurnal Dinamika Mangemen Vol 2 No 2 , 169-180.

Mujahid, N. N. (2018 ). Dampak Keberadaan Mini Market terhadap Warung Kecil di Kota Makassar. Jurnal Sinar Managemen Vol V No 1 , 1.

Nielsen, A. C. (2005). Asia Pacific Retail and Shopper Trends 2005. http://www.acnielsen.de/pubs/documents/RetailandShopperTrendsAsia. 
Oemar, M. (2010). Urgensi Ketentuan Zonasi Pasar Tradisonal dengan Pasar Modern pada Peraturan Daerah Kota Surabaya No 1 Tahun 2010 dalam Apek Hukum Persaingan Usaha. Yuridika Vol 26 No 2 , 151-175.

Rushan. (2016). Analisis Dampak Pertumbuhan Pasar Modern terhadap Eksistensi Pasar Tradisonal Kabupaten Bekasi. Jurnal Ilmiah Ekonomi Mangemen dan Kewirausahaan "Optimal" Vol. 10 No 2, 153-166.

Sarwoko, E. (2008). Dampak Keberadaan Pasar Modern terhadap Kinerja Pedagang Pasar Tradisonal di Wilayah Kota Malang. Jurnal Ekonomi Modernisasi Vol 4 No 2 , 97-115.

Septarini, E. C. (2016). Minimarket Diprediksi Tumbuh 15,5\% hingga 2018. http://industri.bisnis.com.

Sihotang, R. E. (2014). Pengaruh Pasar Modern terhadap Pedagang Tradisional dan Masyarakat dalam Pengembangan Wilayah di Kecamatan Medan Area. Jurnal Ekonom Vol 17 No 4 , 181-194.

Sopiyah, d. S. (2008). Manajemen Bisnis Ritel. Yogyakarta: Penerbit Andi.

Sugiono, S. E. (2012). Dampak Keberadaan Mini Market Terhadap Pedagang Kaki Lima di Sepanjang Jl. MT Haryono Dinoyo Malang. Jurnal Ilmu Sosial dan Ilmu Politik Vol 1 No 2 , 1-4.

Tambunan, T. T. (2004). Kajian Persaingan dalam Industri Retail. Komisi Pengawasa Persaingan Usaha (KPPU).

Tri, J. U. (2011). Persaingan Bisni Ritel: Tradiosional Versus Modern. Fokus Ekonomi Vol 6 No 1 , 122-133.

Wasi, R. B. (2010). Aspek Hukum Zonasi Pasar Tradisonal dan Pasar Modern. Jurnal Dinamika Hukum Vol 10 No 3 , 360-374. 